\title{
Factors Affecting the Prevalence of Healthcare Associated Infections
}

\author{
Amrul Hasan ${ }^{1 *}$, Sularmo $^{2}$, A. Fikri ${ }^{3}$ \\ ${ }^{1,2,3}$ Jurusan Kesehatan Lingkungan Politeknik Kesehatan Tanjungkarang, Indonesia, Jl. Raya Hajimena No. \\ 100 KM. 14 Natar
}

*Corresponding Author: Amrul Hasan, Jurusan Kesehatan Lingkungan Politeknik Kesehatan Tanjungkarang, Indonesia, Jl. Raya Hajimena No.100 KM. 14 Natar, Email: amrulhasan@ gmail.com

\begin{abstract}
Background: Healthcare associated infection (HAI) is an infection experienced by a patient during hospitalization or after discharge from a hospital due to germs obtained at the time the patient is admitted to the hospital.

The Objective: This study aims to determine the prevalence of Healthcare associated infections (HAIs) that occur in public hospitals in Bandar Lampung city, Indonesia.

Method: This research applied cross sectional design with 893 respondents chosen proportionally from 5 (five) general hospitals in Bandar Lampung city. Chi Square test was used to confirm the different causes of Healthcare associated infection (HAI) in various types of hospital.

Result: The result showed that the proportion of HAIs patients in type B general hospital of Bandar Lampung city was $13.77 \%$ and type C hospital was 10.03\%. Several risk factors associated with HAIs incidence in type $B$ hospital were age, the length of stay, infusion and oxygen installation. Among the risk factors associated with the incidence of HAIs in class, $C$ hospital included the length of day care, surgery, infusion, and catheter installation.
\end{abstract}

Conclusion: The results of this study are expected to be used as input for the relevant institutions in preparing the infection prevention and control program in health facilities.

Keywords: Healthcare Associated Infections (HAIs), Day Care, Infusion, Catheter.

\section{INTRODUCTION}

One type of infection is Healthcare Associated Infections from now on abbreviated HAIs which can be interpreted as a disease obtained by a person during the hospital (Darmadi, 2008).

The incidence of HAIs has been used as a benchmark for hospital service quality. In Indonesia, Minister of Health Decree no. 129 of 2008 specifies a minimum standard of hospital services, including reporting of patients receiving HAIs to see how far hospitals exercise control over these infections.

A preliminary study of infections conducted at RSUD Kota Semarang showed that the incidence of nosocomial infection as a whole was 227 patients from 825 patients in inpatient care (Daniati, 2009). The study, conducted in 11 hospitals in DKI Jakarta in 2004, reported that
9.8\% of inpatients received new infections during treatment (Departemen Kesehatan RI, 2009).

Bandar Lampung city as the capital of Lampung province has 19 hospitals divided into 3 (three) classes, namely Class B, Class C and Class D. Throughout the author's knowledge, research on the incidence of HAIs at the General Hospital in Bandar Lampung City has not been much done. This condition was making the data about the prevalence of HAIs at General Hospital in Bandar Lampung City difficult. As such, this study aims to determine the prevalence of Healthcare Associated Infection (HAI) in inpatients at the General Hospital in Bandar Lampung City in 2016. This study is expected to contribute to health care institutions in determining policies related to patient safety. 


\section{MATERIALS AND METHODS}

This research used cross sectional design. The population in this study were all patients who underwent inpatient service at type B and C general hospital in Bandar Lampung city during the research. Samples were patients who underwent hospitalization for more than 3 (three) days at the public hospital in Bandar Lampung city. The number of samples obtained amounted to 893 respondents which were calculated proportionally based on data on the number of hospitalization days in the previous year. Inclusion criteria in this study were patients who underwent hospitalization for more than 3 (three), and the patient's record of medical history was complete.

Chi Square test was used to confirm the different causes of Healthcare associated infection (HAI) in the two types of hospital.

\section{RESUlT}

Table.1. Frequency distribution, percentage of HAIs sufferer, based on type of hospital

\begin{tabular}{|l|l|l|l|l|}
\hline & \multicolumn{2}{|c|}{$\begin{array}{l}\text { TYPE B } \\
\text { Hospital }\end{array}$} & \multicolumn{2}{|c|}{$\begin{array}{l}\text { TYPE C } \\
\text { Hospital }\end{array}$} \\
\hline & 305 & Percentage & $\begin{array}{l}\text { n } \\
588\end{array}$ & Percentage \\
\hline & & & & \\
\hline Phlebitis & & & & \\
\hline Yes & 39 & 12.79 & 59 & 10.03 \\
\hline No & 266 & 87.21 & 529 & 89.97 \\
\hline & & & & \\
\hline $\begin{array}{l}\text { Urinary tract } \\
\text { infection }\end{array}$ & & & & \\
\hline Yes & 3 & 0.98 & & \\
\hline No & 302 & 99.02 & 588 & 100.00 \\
\hline $\begin{array}{l}\text { Infection } \\
\text { Wound } \\
\text { Surgery }\end{array}$ & & & & \\
\hline Yes & & & & \\
\hline No & 303 & 0.69 .34 & 0 & 0.00 \\
\hline HAIs Status & & & 588 & 100.00 \\
\hline No HAIs & 263 & 86.23 & 529 & 89.97 \\
\hline HAIs & 42 & 13.77 & 59 & 10.03 \\
\hline Ages & & & & \\
\hline 0 - 17 Tahun & 81 & 26.56 & 117 & 19.90 \\
\hline 18 - 65 Tahun & 193 & 63.28 & 400 & 68.03 \\
\hline 66 - 79 Tahun & 22 & 7.21 & 58 & 9.86 \\
\hline$>$ 79 Tahun & 9 & 2.95 & 13 & 2.21 \\
\hline Gender & & & & \\
\hline Men & 182 & 59.67 & 300 & 51.02 \\
\hline Women & 123 & 40.33 & 288 & 48.98 \\
\hline $\begin{array}{l}\text { Length } \\
\text { Care }\end{array}$ & & & & \\
\hline - 5 Days & 228 & 74.75 & 557 & 94.73 \\
\hline 6 - 10 Days & 51 & 16.72 & 27 & 4.59 \\
\hline$>$ 10 Days & 26 & 8.52 & 4 & 0.68 \\
\hline
\end{tabular}

\begin{tabular}{|l|l|l|l|l|}
\hline $\begin{array}{l}\text { Treatment } \\
\text { Ward }\end{array}$ & & & & \\
\hline $\begin{array}{l}\text { VIP and } 1^{\text {st }} \\
\text { Class }\end{array}$ & 7 & 2.3 & 103 & 17.52 \\
\hline $2^{\text {nd }}$ Class & 30 & 9.84 & 18 & 3.06 \\
\hline $3^{\text {rd }}$ Class & 268 & 87.87 & 467 & 79.42 \\
\hline Surgery & & & & \\
\hline Yes & 115 & 37.7 & 124 & 21.09 \\
\hline No & 190 & 62.3 & 464 & 78.91 \\
\hline Transfusion & & & & \\
\hline No & 266 & 87.5 & 585 & 99.49 \\
\hline Yes of & 38 & 12.5 & 3 & 0.51 \\
\hline $\begin{array}{l}\text { Installation } \\
\text { Infusion }\end{array}$ & 113 & 37.05 & 312 & 53.06 \\
\hline Once & 123 & 40.33 & 248 & 42.18 \\
\hline Twice & 69 & 22.62 & 28 & 4.76 \\
\hline Three Times & & & \\
\hline $\begin{array}{l}\text { Installation of } \\
\text { Catheter }\end{array}$ & & & & \\
\hline $\begin{array}{l}\text { Without } \\
\text { Catheter }\end{array}$ & 242 & 79.34 & 513 & 87.24 \\
\hline With Catheter & 63 & 20.66 & 75 & 12.76 \\
\hline & & & & \\
\hline $\begin{array}{l}\text { Installation } \\
\text { Oxygen }\end{array}$ & & & & \\
\hline With Oxygen & 270 & 88.52 & 567 & 96.43 \\
\hline $\begin{array}{l}\text { Without } \\
\text { Oxygen }\end{array}$ & 35 & 11.48 & 21 & 3.57 \\
\hline & & & & \\
\hline
\end{tabular}

Out of 893 patients treated for more than three days in a public hospital in Bandar Lampung, the proportion who received HAIs was $11.31 \%$. Meanwhile, based on hospital type, the proportion of HAIs male was $12.45 \%$ more than women patients who received HAIs as much as $9.98 \%$. In the other hand, more female patients did not suffer from HAIs compared to the male patient. The proportion of patients receiving HAIs in the 18-65 year age group was less than in the 66-79 age group. Based on the variable length of the day of stay, the proportion of patients receiving HAIs was more likely in patients with 6 to 10 days of hospitalization (28.21\%) followed by more than ten days of hospitalization of $23.33 \%$.

Respondents who were treated in $3^{\text {rd }}$ class and isolation room received more HAIs $(12.65 \%)$ compared to respondents who were treated in $1^{\text {st }}$ class and VIP $(3,654 \%)$ and $2^{\text {nd }}$ class as much as $8.33 \%$. Respondents who got infusion three times got HAIs $12.65 \%$ more than respondents who got infusion two times $(8.33 \%)$ and one infusion of $3.64 \%$. Likewise, with catheter installation, respondents who received catheter installation twice got HAIs of $25 \%$. Slightly different from the infusion and catheter installation, the respondents who got the first 
oxygen facility got more HAIs (40\%), while the respondents who got the oxygen setup twice as much as $18.75 \%$ while the respondents who did not get the oxygen installation got HAIs as much as $9.43 \%$.

Based on age group, there is a difference of opportunity to get HAIs based on age group in type $\mathrm{B}$ and type $\mathrm{C}$ hospitals. The age group in type $\mathrm{B}$ hospital is related to HAIs incidence with $\mathrm{p}$ - value $=0.008$ whereas in type $\mathrm{C}$ hospital there is no relationship between age group and HAIs with $\mathrm{p}$ - value $=0.0445$.

The association of gender with Healthcare Associated Infection in public hospital in Bandar Lampung City that the opportunity to get HAIs in type $\mathrm{B}$ hospital with $\mathrm{p}-$ value $=$ 0,512 and in class $\mathrm{C}$ hospital with $\mathrm{p}$ - value $=$ 0.426 . The result of the analysis of the length of the day of care with the incidence of Healthcare Associated Infection indicates there is a relationship between the length of stay with the opportunity to get HAIs both in type B and type $\mathrm{C}$ with $\mathrm{p}$ - value $=0.000$ and 0.002 respectively.

Based on the treatment ward class, patients treated in the third grade and isolation room did not differ in the chance of suffering HAIs in type B hospital with $\mathrm{p}$ - value $=0.529$. However, in type $\mathrm{C}$ hospital there was a difference of opportunity between patient treated in VIP room and $1^{\text {st }}$ Class with patients treated in $2^{\text {nd }}$ class and $3^{\text {rd }}$ class with the $p$ value $=0.000$.

The surgical action is a risk factor for HAIs incidence where patients treated in type B hospital are not likely to get HAIs with a $\mathrm{p}$ value $=0.529$.Furthermore, in hospital type $\mathrm{C}$ there is a difference in percentage of patients who get surgery and patients who are not receiving surgery with a $\mathrm{p}$ - value $=0.000$.

Transfusion is one of the risk factors for transmission of HAIs in hospitals. The results of this study found no difference between patients receiving transfusions and patients who did not receive transfusions with HAIs both in type $\mathrm{B}$ and type $\mathrm{C}$ hospital with $\mathrm{p}$ - value $=0.379$ and 0.562 . Installation of infusion is one of the risk factors of HAIs. The results of this study found that there was a difference between patients who received infusion and patients who did not get infused with the incidence of HAIs both in type $\mathrm{B}$ and type $\mathrm{C}$ hospital with $\mathrm{p}$ - value $=0000$.

There is a difference between patients who get catheter insertion with patients who do not get catheter installation with the incidence of HAIs in type $\mathrm{B}$ hospital with $\mathrm{p}-$ value $=0.172$. In class $\mathrm{C}$ hospital there is a difference between patients who get catheter with patients not got catheter insertion with HAIs incidence with pvalue $=0.000$.

In contrast, patients receiving oxygen in type B hospital with patients who did not get oxygen installation with HAIs incidence with the $p$ value of 0.002 while in type $C$ hospital $p$-value was 0.032 .

\section{DISCUSSION}

Infectious diseases are still one of the world's health problems, including Indonesia. Infection can come from a community (Community acquired infection) or from a hospital acquired infection (formerly known as nosocomial infection). Medical measures taken by health personnel intended for treatment or cure of the patient, if performed are not by the procedure has the potential to transmit infectious diseases, either to the patient (other) or even to the health worker itself. To be able to perform infection prevention and control, especially hospital infections, need to have knowledge of the basic concepts of infectious diseases.

The results of this study found that the prevalence of HAIs patients in public hospitals in Bandar Lampung city was $13.77 \%$ in hospital type B and $10.03 \%$ in class C hospital. This result indicated that transmission of HAIs in hospitals in Bandar Lampung Still occurs. This condition can be caused by several factors such as cleanliness of the patient's treatment room environment, hand hygiene measures by health personnel. The prevalence of HAIs is probably much smaller than the actual results because the incidence of HAIs in hospitals is still an iceberg phenomenon. But these results are sufficient to give an idea of the prevalence of HAIs in public hospitals in Bandar Lampung City.

The prevalence of HAIs in this study is higher than that of Malhotra ( 2014) by $8.87 \%$, while Riva (2013) found HAIs patients in the General Hospital of Sarjito Yogyakarta at $7.8 \%$.

The high incidence of HAIs in public hospitals in the city of Bandar Lampung allegedly related to the ineffective implementation of hand hygiene conducted by officers who provide services to patients. In Indonesia, research conducted at 11 hospitals in DKI Jakarta in 2004 showed that $9.8 \%$ of inpatients received nosocomial infection (Departement Kesehatan, 2008). 
By gender, there was no difference in the proportion between male and female sexes suffering from HAIs in type B hospital ( $\mathrm{p}$ value $=0.51)$ as well as in hospital type $\mathrm{C}$ ( $\mathrm{p}$ value $=$ $0.63)$. This study is in line with a study by Shelley, et.al (2014) who found no difference in the proportion of male and female sex with a $p$ value of 0.13. Age is a major factor in the transmission of HAIs in hospitals. The results of this study found by age the proportion of patients with the greatest HAIs experienced by age group $>79$ years of $33.33 \%$ in hospital type $\mathrm{B}$, whereas in general hospital type $\mathrm{C}$ no $\mathrm{A}$ significant difference in each age group. This conclusion is in line with the research conducted in England that the older age group the chances of getting HAIs was getting bigger (Shelley, 2014).

The results of this study found that patients treated for 6-10 days have a greater chance of suffering from HAIs compared with patients who were treated more than ten days in both type $\mathrm{B}$ and type $\mathrm{C}$ hospitals. The results of this study are not in line with research conducted by Nguyen (2009) who found that patients treated for 4-5 days had a greater risk than patients treated for 5-10 days or> 10 days.

Based on the type of action given to the patient to provide care and treatment to the patients, those who have infusion three times more likely to get HAIs compared with patients who received a one-time infusion. Whereas patients who received the first-ever catheter insertion got HAIs compared with patients, who did not get the catheter installation. Patients who received oxygenation were more likely to get HAIs than patients who did not get oxygenated.

\section{CONClusion}

The results of this study concluded that the prevalence of patients treated in public hospitals in Bandar Lampung city was infected by Healthcare Associated Infection (HAIs) overall during hospitalization was $11.31 \%$. This figure was $13.77 \%$ in type B hospital and $10.03 \%$ in class $\mathrm{C}$ hospital. Several risk factors suspected to be associated with HAIs incidence in type B hospital are age, the length of stay, infusion and oxygen installation. Risk factors alleged to be involved in the incidence of HAIs in type $\mathrm{C}$ hospital are the length of day care, surgery, infusion and installation of catheters.

\section{REFERENCES}

[1] Darmadi. 2008. Infeksi Nosokomial : Problematika Dan Pengendaliannya. Jakarta : Penerbit Salemba Medika.

[2] Departemen Kesehatan RI, 2008: Keputusan Menteri Kesehatan Nomor: 129/Menkes/ Sk/Ii/ 2008 Tentang Standar Pelayanan Minimal Rumah Sakit.

[3] Departemen Kesehatan RI, 2009 : Pedoman Pencegahan dan Pengendalian Infeksi di Rumah Sakit dan Fasilitas Pelayanan Kesehatan Lainnya.ed 2, Jakarta.

[4] Malhotra S, Sharma S, Hans C, 2014, Prevalence of Hospital Acquired Infections in a tertiary care hospital in India, 92 Int. Inv. J. Med. Med. Sci.

[5] Nguyen QV. 2009, Hospital-acquired infections. Last updated 2009 Jan 14. [disitasi 22 Juli 2016]. available at: www.emedicine. medscape.com/ article/967022-overview.

[6] Riva, Fridawaty, 2013, Determinan Infeksi Luka Operasi Pascabedah Sesar, Kesmas, Jurnal Kesehatan Masyarakat Nasional Vol. 8, No. 5, Desember 2013

[7] Shelley S. Magill, 2014, Multistate PointPrevalence Survey of Health Care-Associated Infections, The new England journal o $\mathrm{f}$ medicine, n Engl j med 370;13 nejm.org march $27,2014$.

Citation: Amrul Hasan, Sularmo \& A. Fikri. Factors Affecting the Prevalence of Healthcare Associated Infections. ARC Journal of Public Health and Community Medicine.2017; 2(3):29-32: dx.doi.org/10.20431/ 2456-0596.0203006

Copyright: (c) 2017 Authors. This is an open-access article distributed under the terms of the Creative Commons Attribution License, which permits unrestricted use, distribution, and reproduction in any medium, provided the original author and source are credited. 